\title{
In vivo antinuclear antibody of the skin: diagnostic significance and association with selective antinuclear antibodies
}

\author{
P J Velthuis, L Kater, I van der Tweet, F Gmelig Meyling, R H W M Derksen, \\ R J Hené, J A van Geutselaar, H Baart de la Faille
}

\begin{abstract}
Immunofluorescence microscopy of the skin has disclosed antibodies bound to epidermal cell nuclei in several connective tissue disorders. To establish the diagnostic potential of this phenomenon the results of immunofluorescence microscopy of biopsy specimens from 1651 subjects with various diseases and from 315 patients with systemic connective tissue disorders and related diseases were reviewed. It was found that the predictive value of the phenomenon for the presence of a systemic connective tissue disorder was, in general, $88 \%$. Except for the homogeneous and thready patterns, which seldom appear, but are specific for SLE, in vivo antinuclear antibody (ANA) does not discriminate better between the various disorders than do serum antibodies. The presence of in vivo ANA in the skin was related to serum antibodies against non-histone nucleoproteins, but not to anti-dsDNA antibodies. Combined with the finding that antibodies against non-histone nucleoproteins can bind on the surface of human keratinocytes, this suggests that ANA of the skin occurs in vivo.
\end{abstract}

Antinuclear antibodies (ANAs) are commonly found in the blood of patients with systemic connective tissue disorders (SCTDs)-that is, systemic lupus erythematosus (SLE), scleroderma, dermatomyositis/polymyositis, Sjögren's syndrome, mixed connective tissue disease, and rheumatoid arthritis. Immunofluorescence microscopy of skin biopsy specimens from both clinically involved and uninvolved skin in these disorders has shown antibodies bound to epidermal cell nuclei (in vivo ANA of the skin). ${ }^{1-10}$ In most disorders the prevalence of the phenomenon has not been investigated systematically, whereas in others-for example, SLE, the results vary widely (table 1 ). The

Table 1: Prevalence of in vivo antinuclear antibody in various connective tissue disorders. The data have been extracted from published work and the values are given as a percentage with the number of patients tested in parentheses

\begin{tabular}{|c|c|c|c|c|}
\hline Diagnosis & Prevalence & & & \\
\hline $\begin{array}{l}\text { SLE* } \\
\text { MCTD* } \\
\text { Systemic sclerosis } \\
\text { CREST* } \\
\text { Dermatomyositis/polymyositis } \\
\text { Rheumatoid arthritis } \\
\text { Primary Raynaud's disease } \\
\text { Discoid LE } \\
\text { Primary biliary cirrhosis } \\
\text { Chronic aggressive hepatitis } \\
\text { Pulmonary fibrosis }\end{array}$ & $\begin{array}{r}45(33)^{6} \\
100(16)^{6} \\
47(17)^{6} \\
15(20)^{6} \\
29(7)^{3} \\
\text { Incidentally }\end{array}$ & $\begin{array}{r}29(7)^{3} \\
100(15)^{4} \\
50(10)^{8}\end{array}$ & $\begin{array}{rr}6 & (153)^{1} \\
80 & (5)^{5} \\
50 & (10)^{8}\end{array}$ & $75(8)^{8}$ \\
\hline
\end{tabular}

${ }^{*}$ SLE =systemic lupus erythematosus; $M C T D=$ mixed connective tissue disease; $C R E S T=$ calcinosis, Raynaud's phenomenon, oesophageal dysmotility, sclerodactyly, telangiectasia. diagnostic significance of the phenomenon is unknown, particularly for the predictive value for the presence of SCTD, and the yield of additional information for the diagnosis of SCTD compared with routine serum tests. The pathophysiology of the phenomenon is also disputed.

To study the diagnostic significance we designed a retrospective study, in which we reviewed the results of immunofluorescence microscopy of biopsy specimens from 1651 subjects with various disorders and from 315 patients with different SCTD sor related diseases. We found a significant association between in vivo ANA of the skin and the presence of serum antibodies against the non-histone nucleoproteins SSA/Ro, SSB/La, RNP, and Sm. No association with anti-dsDNA in the serum was found, however. Together with information from studies on keratinocyte cultures ${ }^{11}$ and cell suspensions of keratinocytes ${ }^{12}$ this argues against the possibility that the in vivo ANA phenomenon is due to artefacts.

\section{Patients and methods}

PATIENTS

The study was in two parts.

The first part concerned the predictive value of a positive test-namely, the chance of an SCTD, given the presence of in vivo ANA of the skin. The results of all 1651 biopsies of clinically healthy skin from the University Hospital (Utrecht) processed in our laboratory between 1983 and 1987 were reviewed, as were the clinical and serological records of all patients.

The second part of the study concerned the prevalence of in vivo ANA of the skin, defined as the percentage of persons with a specific SCTD or related disorder, showing in vivo ANA of the skin. This involved 250 patients with an SCTD, and 65 with a related disorder (primary Raynaud's phenomenon (42 patients), localised scleroderma (14), Wegener's disease (two), periarteritis nodosa (seven)), who visited the outpatient clinics of the departments of rheumatology, immunopathology, or dermatology in Utrecht University Hospital in 1987, and in whom a skin biopsy on clinically healthy skin had been performed.

\section{DIAGNOSTIC CRITERIA}

Patients with systemic lupus erythematosus and rheumatoid arthritis fulfilled the American Rheumatism Association criteria. ${ }^{13} 14$ The diagnoses discoid and subacute cutaneous lupus erythematosus were based on clinical, histo- 

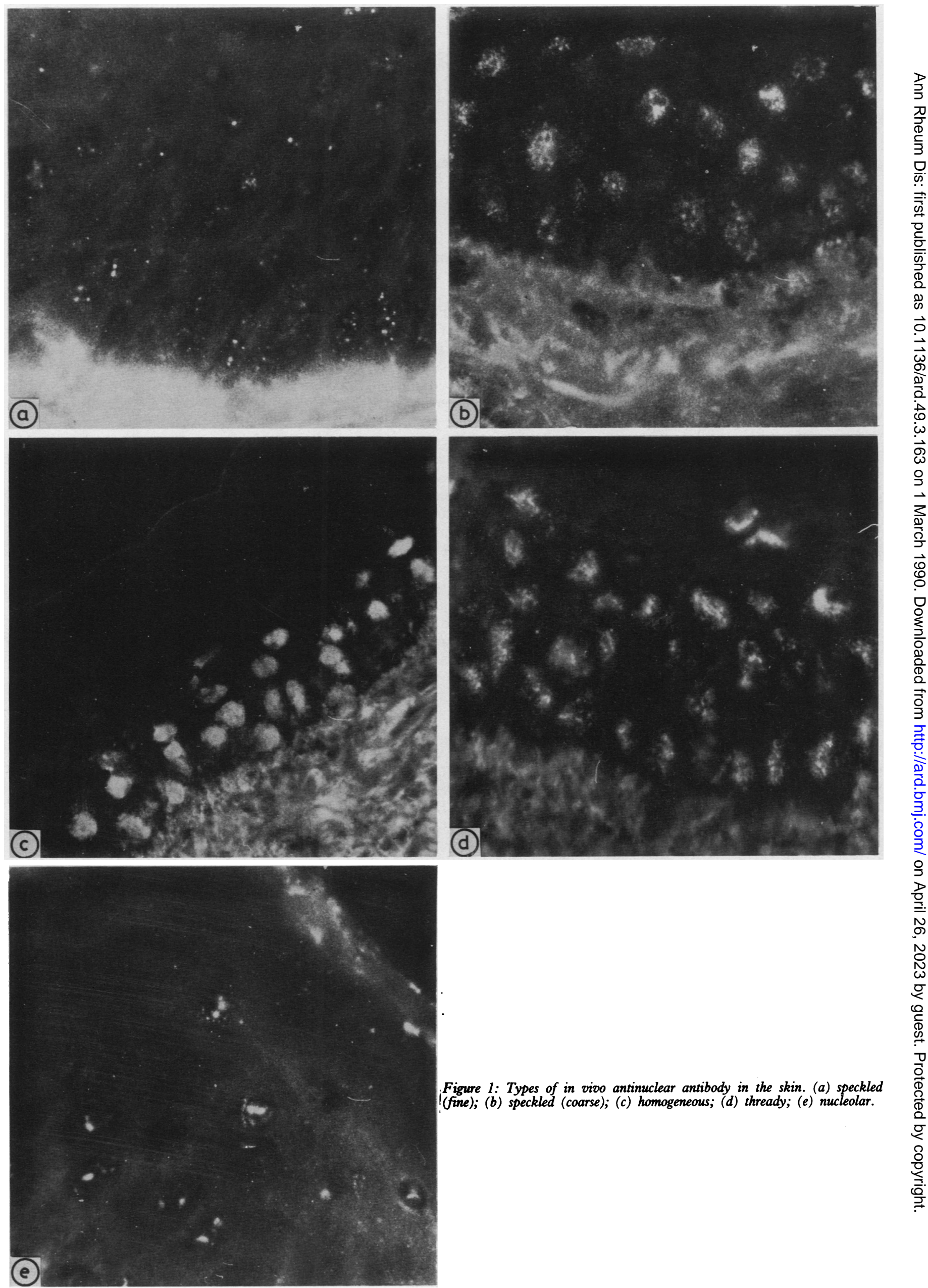

Figure 1: Types of in vivo antinuclear antibody in the skin. (a) speckled

(fine); (b) speckled (coarse); (c) homogeneous; (d) thready; (e) nucleolar. 
logical, and immunofluorescence features. For the diagnoses dermatomyositis/polymyositis, different forms of scleroderma, Sjögren's syndrome, and mixed connective tissue disease widely accepted criteria were used. ${ }^{15}$ If symptoms of two different connective tissue disorders were found the patient was classified as 'overlap syndrome'. Patients diagnosed as having Raynaud's phenomenon had at least symmetrical biphasic colour changes in the hands or feet, precipitated by cold or emotion.

\section{IMMUNOFLUORESCENCE}

Punch biopsy specimens $(3 \mathrm{~mm}$ ) were taken from the clinically normal skin of the extensor surface of the forearm. The specimens were snap frozen in liquid nitrogen and stored at $-70^{\circ} \mathrm{C}$ for a maximum of one week before processing. Frozen tissue was cut at $4 \mu \mathrm{m}$ and sections were air dried and then washed in

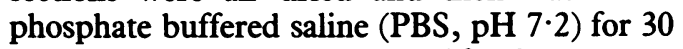
minutes. All sections were tested for the presence of IgA, IgG, IgM, and C3 using commercially available fluorescein isothiocyanate conjugates (Dakopatts, Copenhagen) by incubation in a humid chamber at room temperature for 30 minutes. The sections were then washed again in PBS for 30 minutes and mounted under glass cover slips with a solution of $10 \%$ glycerol in PBS. Specificity of all serum samples was tested by crossed immunoelectrophoresis, and on plasma cells of bone marrow, jejunum, and lymph nodes from various subjects. Optimal working dilutions were established by chess board titrations on frozen skin sections with a known specific immunofluorescence pattern; these were found to be 1:30 in PBS for all conjugates used. All slides were assessed by a Zeiss microscope, equipped for dark field fluorescence. Four different in vivo ANA staining patterns were distinguished (fig 1): speckled (fine and coarse), homogeneous, thready, and nucleolar.

\section{SERUM SAMPLES}

The occurrence of IgG class ANA in the serum was tested by indirect immunofluorescence on

Table 2: Final diagnoses in 75 patients with in vivo antinuclear antibody of the skin. Number of patients is shown

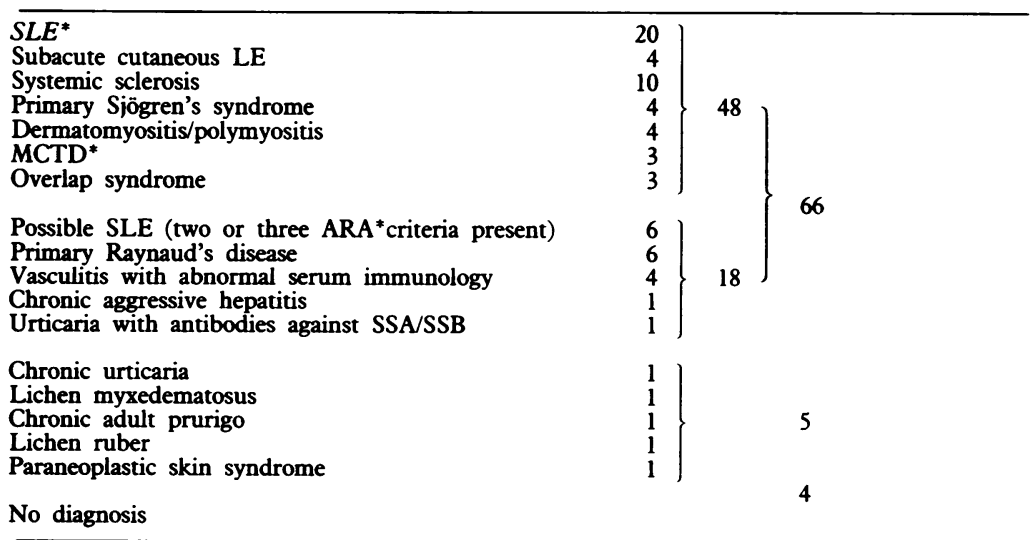

Predictive value $=88 \%(66 / 75)$.

${ }^{*}$ SLE = systemic lupus erythematosus; $M C T D=$ mixed connective tissue disease; $A R A=A m e r i c a n$ Rheumatism Association. mouse liver sections. Only those serum tests performed within two weeks before or after the date of biopsy were considered. Titres $1 / 100$ and 1/1000 (maximal routinely performed dilution in our laboratory) were considered positive. The ANA pattern recorded was that found at the highest positive dilution. Antibodies against extractable nuclear antigens, ribonucleoprotein, Sm, SSA, and SSB were tested by counterimmunoelectrophoresis with reference sera from CDC (Atlanta). Antibodies against dsDNA were tested by indirect immunofluorescence on Crithidia luciliae and by radioimmunoassay (Farr test).

\section{STATISTICS}

All tests for statistical associations were performed with the Fisher exact test, except for the association between skin and serum ANA patterns when McNemar's test for paired observations was used. Probabilities $\leqslant 0.05$ were considered significant.

\section{Results}

\section{PREDICTIVE VALUE OF A POSITIVE TEST}

In $75(4.5 \%)$ of 1651 skin biopsies IgG in vivo ANA was found (two cases also showed IgA deposits). Table 2 summarises the diagnoses of these 75 patients. In 48 a final diagnosis of an SCTD was made; 18 had clinical signs compatible with an SCTD but insufficient criteria for definite classification; five had a disorder not related to an SCTD, and in four patients the data were insufficient for a final diagnosis. Thus the predictive value in this group was $88 \%$ $(66 / 75)$. Of the 75 patients with in vivo ANA, 60 showed a speckled staining pattern, two a homogeneous pattern (both SLE), two thready (both SLE), four had a combination of these patterns (two SLE, one polymyositis, and one Raynaud's disease). A nucleolar pattern was found in seven patients (six with systemic sclerosis and one with Raynaud's disease).

INCIDENCE OF IN VIVO ANA OF THE SKIN

Table 3 shows the prevalence of in vivo ANA (all exclusively IgG) in healthy skin for different SCTDs, together with the prevalence of serum ANA at a titre $\geqslant 1 / 100$ and of the specific antibodies. A statistically significant association between in vivo ANA and serum ANA was found in acrosclerosis, overlap syndrome, dermatomyositis/polymyositis type 5-namely, associated with another SCTD, ${ }^{15}$ secondary Raynaud's phenomenon, and primary Sjögren's syndrome. In mixed connective tissue disease both serum ANA and in vivo ANA were invariably positive, whereas in localised scleroderma, Wegener's disease, and periarteritis nodosa both were negative in every case. Table 4 shows the statistical association between in vivo ANA of the skin and the different types of specific serum autoantibodies; patients were considered in two groups-with and without lupus erythematosus, as numbers were too small to test every disorder by itself. A statistically significant association was found between 
Table 3: In vivo antinuclear antibody of the skin in patients with different types of connective tissue disorders. Values are given as a percentage with the number of patients tested in parentheses

\begin{tabular}{|c|c|c|c|c|c|c|c|c|}
\hline \multirow[t]{2}{*}{ Diagnosis } & \multicolumn{2}{|l|}{$A N A^{*}$} & \multirow[t]{2}{*}{$E N A^{*}$} & \multirow[t]{2}{*}{$S S A$} & \multirow[t]{2}{*}{$S S B$} & \multirow[t]{2}{*}{$S m$} & \multirow[t]{2}{*}{$R N P$} & \multirow[t]{2}{*}{$d s D N A$} \\
\hline & In vivo & Serum & & & & & & \\
\hline $\begin{array}{l}\text { Lupus erythematosus } \\
\text { Systemic } \\
\text { Discoid } \\
\text { Subacute cutaneous }\end{array}$ & $\begin{array}{r}26(66) \\
5(55) \\
32(28)\end{array}$ & $\begin{array}{l}84(59) \\
\$ 5(50) \\
14(20)\end{array}$ & $\begin{array}{r}36(28) \\
9(23) \\
30(20)\end{array}$ & $\begin{array}{r}20(24) \\
7(27) \\
61(18)\end{array}$ & $\begin{array}{r}22(23) \\
0(21) \\
22(18)\end{array}$ & $\begin{array}{r}25(24) \\
0(21) \\
13(16)\end{array}$ & $\begin{array}{r}12(22) \\
9(23) \\
12(17)\end{array}$ & $\begin{array}{r}66(59) \\
3(37) \\
23(22)\end{array}$ \\
\hline $\begin{array}{l}\text { Scleroderma } \\
\text { Acrosclerosis } \\
\text { Localised }\end{array}$ & $\begin{array}{r}56(36) \\
0(14)\end{array}$ & $\begin{array}{l}\| 44(25) \\
0(4) \|\end{array}$ & $14(21)$ & $\begin{array}{c}0(18) \\
\text { - Not tested }\end{array}$ & $0(18)$ & $0(18)$ & $10(20)$ & $5(22)$ \\
\hline Rheumatoid arthritis & $7(27)$ & $15(14)$ & $8(13)$ & $0(8)$ & $0(8)$ & $0(7)$ & $8(12)$ & $8(12)$ \\
\hline $\begin{array}{l}\text { MCTD* } \\
\text { Overlap syndrome } \neq\end{array}$ & $\begin{array}{r}100(6) \\
71(17)\end{array}$ & $\begin{array}{l}100 \text { (6)ף } \\
\| 59(17)\end{array}$ & $\begin{array}{r}100(6) \\
62(13)\end{array}$ & $\begin{aligned} 0 & (6) \\
40 & (10)\end{aligned}$ & $\begin{array}{rr}0 & (6) \\
33 & (9)\end{array}$ & $\begin{array}{l}0(6) \\
0(12)\end{array}$ & $\begin{aligned} 100 & (6) \\
33 & (9)\end{aligned}$ & $\begin{array}{l}33(6) \\
19(16)\end{array}$ \\
\hline $\begin{array}{l}\text { Wegener's disease and } \\
\text { periarteritis nodosa }\end{array}$ & 0 & $0(9) \pi$ & & - Not tested & & & & \\
\hline $\begin{array}{l}\text { Myositis } \\
\text { Types } 1-4 \\
\text { Type } 5 \ddagger\end{array}$ & $\begin{array}{l}40(20) \\
80(15)\end{array}$ & $\begin{array}{r}24(17) \\
\| 61(13)\end{array}$ & $\begin{array}{ll}17 & (6) \\
66 & (9)\end{array}$ & $\begin{array}{rr}0 & (2) \\
100 & (3)\end{array}$ & $\begin{array}{ll}20 & (5) \\
20 & (5)\end{array}$ & $\begin{array}{ll}0 & (5) \\
0 & (5)\end{array}$ & $\begin{array}{rr}0 & (5) \\
50 & (8)\end{array}$ & $\begin{array}{r}0(18) \\
33(12)\end{array}$ \\
\hline $\begin{array}{l}\text { Raynaud's syndrome } \\
\text { Primary } \\
\text { Secondary } \neq\end{array}$ & $\begin{array}{l}12(42) \\
38(92)\end{array}$ & $\left\{\begin{array}{l}19(31) \\
\| 36(82)\end{array}\right.$ & $\begin{array}{r}0(16) \\
29(51)\end{array}$ & $\begin{array}{r}0(14) \\
38(21)\end{array}$ & $\begin{array}{r}0(12) \\
13(40)\end{array}$ & $\begin{array}{r}0(12) \\
17(41)\end{array}$ & $\begin{array}{r}0(12) \\
20(41)\end{array}$ & $\begin{array}{r}0(13) \\
35(49)\end{array}$ \\
\hline $\begin{array}{l}\text { Sjögren’s syndrome } \\
\text { Primary } \\
\text { Secondary } \ddagger\end{array}$ & $\begin{array}{l}65(20) \\
60(10)\end{array}$ & $\begin{aligned} \| 45(16) \\
50(8)\end{aligned}$ & $\begin{array}{l}60(15) \\
50(6)\end{array}$ & $\begin{array}{l}66(15) \\
20(5)\end{array}$ & $\begin{array}{l}60(15) \\
40(5)\end{array}$ & $\begin{array}{l}0(16) \\
0(7)\end{array}$ & $\begin{array}{r}8(12) \\
50(6)\end{array}$ & $\begin{array}{r}0(12) \\
62(8)\end{array}$ \\
\hline
\end{tabular}

*ANA=antinuclear antibody; ENA=extractable nuclear antigen; MCTD=mixed connective tissue disease.

$\dagger$ Eight patients are also included under the diagnosis systemic lupus erythematosus.
†These patients are also included in another diagnostic group.

Fisher's test biased by a large number of negative test results.

IStatistically significant association between in vivo ANA and serum ANA.

$\llbracket$ No statistical test possible because no positive or negative reactions were found.

Table 4: Statistical associations of in vivo antinuclear antibody (ANA) of the skin with serum ANA and specific serum autoantibodies. Values in parentheses show the number of patients tested

\begin{tabular}{llllllrl}
\hline & ANA & ENAt & SSA & SSB & \multicolumn{1}{l}{$S m$} & \multicolumn{1}{c}{$n R N P$} & dsDNA \\
\hline $\begin{array}{l}\text { Lupus erythematosus } \\
\text { Other disorders }\end{array}$ & $\mathrm{NS}^{*}(122)$ & ${ }^{*}(70)$ & ${ }^{*}(67)$ & ${ }^{*}(62)$ & ${ }^{*}(60)$ & ${ }^{*}(60)$ & NS (112) \\
\hline
\end{tabular}

${ }^{*} \mathrm{p}<0.05 ;{ }^{* *} \mathrm{p}=0.09$.

†ENA = extractable nuclear antigen.

$\ddagger$ Neg indicates that all serum tests were negative.

the presence of in vivo ANA of the skin and antibodies against SSA, SSB, RNP, and Sm in the serum, but not with serum antibodies against dsDNA. For both groups with SCTD (patients with and without lupus erythematosus) it was found that according to McNemar's test the chances for the presence of a speckled type ANA were significantly higher in the skin (80\%) than in the serum $(55 \%)$, whereas the chances of a homogeneous ANA pattern were significantly higher in the serum (30\%) than in the skin (2\%).

\section{Discussion}

The first part of this study concerned the predictive value of a positive ANA in vivo. We found that when in vivo ANA of clinically healthy skin is discovered in a patient there is an $88 \%$ chance that the patient has an SCTD.

In the second part of this study the prevalence of in vivo ANA of the skin in different connective tissue disorders was investigated. The data found are comparable with those published by others (table 1), except for the presence of in vivo ANA in dermatomyositis/ polymyositis, which has only occasionally been noted before. ${ }^{3}$ We found a positive in vivo ANA in 20 out of 35 patients $(57 \%)$ with dermatomyositis/polymyositis. In the subgroup associated with other SCTDs (subgroup 5) a prevalence of $80 \%$ was found.

In several disorders the prevalence of in vivo ANA varied among different subforms, which may indicate a diagnostic potential. There is a significant association, however, between in vivo ANA and serum ANA in all SCTDs, except SLE, subacute cutaneous lupus erythematosus, and rheumatoid arthritis. In SLE and rheumatoid arthritis the serum ANA $84 \%$ and $15 \%$ respectively) is a better diagnostic variable than the in vivo ANA ( $26 \%$ and $7 \%$ respectively), whereas in subacute cutaneous lupus erythematosus the presence of serum antibodies against SSA $(61 \%)$ can be considered a far better diagnostic marker than in vivo ANA (32\%). It seems that serum antibodies discriminate between the various SCTDs at least as well as positive in vivo ANA of clinically healthy skin.

The pattern of in vivo ANA, however, can provide diagnostic information. The thready and homogeneous in vivo ANA patterns, though seldom found, occurred exclusively in SLE. The nucleolar pattern was found to be very specific for scleroderma, as had been noted by Prystowsky and others, ${ }^{7}$ but this was both in skin and serum (predictive value, $86 \%$ and $80 \%$ respectively). Recently it has been found that in addition to the speckled type nuclear staining, 
patients with primary Sjögren's syndrome may also show speckled IgG deposits in the cytoplasm of epidermal cells (fig 2). ${ }^{9}$ In general, speckled ANA patterns were found significantly more often in skin than in serum, whereas the homogeneous pattern was found more commonly in serum than in skin. This may be the result of incomplete dilution of the serum, of the difference in the tissues involved (human skin and mouse liver), or of differences in interpretation of the immunofluorescence patterns.

Both in lupus erythematosus and in the other SCTDs the presence of in vivo ANA of the skin was associated with antibodies against nonhistone nucleoproteins - that is, SSA, SSB, RNP, Sm, but not with antibodies against dsDNA. As antibodies against both dsDNA and non-histone nucleoproteins can bind to epidermal cell nuclei in sections of human skin, such an association cannot be explained if the 'in vivo ANA' phenomenon has been caused by passive diffusion-for example, during incubation of the sections. Therefore we concluded that the deposition of antibodies in epidermal cell nuclei is at least partly controlled by a mechanism that selects for antibodies against non-histone nucleoproteins and against antidsDNA antibodies.

The greatest barrier for the in vivo binding of an antibody to the keratinocyte nucleus is the epidermal cell membrane. Antibodies are not able to permeate the membrane of vital keratinocytes by simple diffusion. ${ }^{11}{ }^{16}$ In studies on the binding of antibodies on the cell surface of

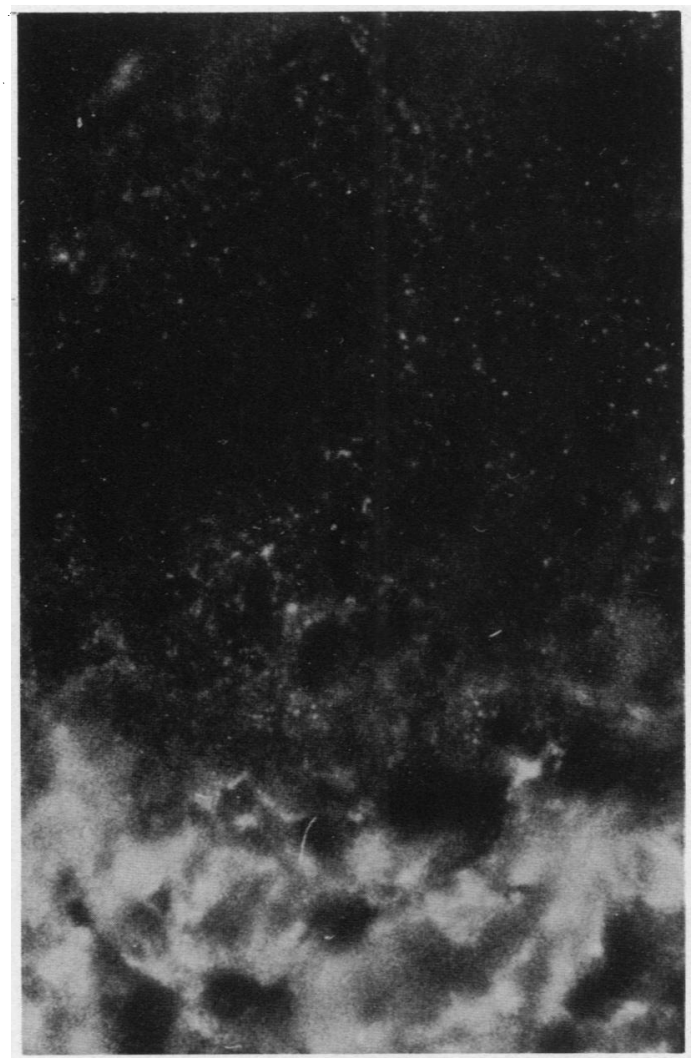

Figure 2: Speckled epidermal nuclear and cytoplasmic IgG deposits in the skin of a patient with primary Sjögren's syndrome. keratinocytes in suspensions and in culture it was found that antibodies against non-histone nucleoproteins did bind, whereas antibodies against dsDNA did not. ${ }^{11} 12$ This suggests that selective binding of antibodies against nonhistone nucleoproteins on the cell surface, followed by active incorporation of the bound antibody, controls the formation of in vivo ANA in the skin.

\section{Conclusion}

The presence of in vivo ANA in the clinically healthy skin is a phenomenon with a high predictive value for a systemic connective tissue disorder. Its diagnostic value in discriminating between the various SCTDs is low, however, compared with serum antibodies. This does not eliminate the use of immunofluorescence microscopy in SCTD as staining at the basal membrane zone was not included in this study. The selective association between in vivo ANA in the skin and non-histone nucleoprotein antibodies in the blood suggests that we are dealing with a phenomenon occurring in vivo.

The authors gratefully acknowledge the skilful technical assistance of Miss G C F de Bruin and Miss J J Nefkens.

1 Baart de la Faille-Kuyper E H. In-vivo nuclear localization of immunoglobulins in clinically normal skin in systemic and procainamide induced lupus erythematosus. Neth 7 Med 1974; 17: 58-65

2 Bentley-Phillips C B, Geake T M S. Mixed connective tissue disease characterized by speckled epidermal nuclear IgG deposition in normal skin. Br 7 Dermatol 1980; 102: 529-33.

3 Chen Z-I, Dobson R L, Ainsworth S K, Silver R M, Maricq H R. Epidermal nuclear immunofluorescence: serological correlations supporting an in vivo reaction. Br f Dermato correlations supportin

4 Gilliam J N, Prystowski S D. Mixed connective tissue disease syndrome. Arch Dermatol 1977; 113: 583-7.

5 Izuno G T. Observations on the in vivo reaction of antinuclear antibodies with epidermal cells. Br $\mathcal{F}$ Dermatol 1978; 98 $391-8$.

6 Kallenberg C G M, de Jong M C J M, Walstra T M, Kardaun $S$, The $T H$. In vivo antinuclear antibodies (ANA) in biopsies of normal skin: diagnostic significance and relation to serum ANA. F Rheumatol 1983; 10: 733-40.

7 Prystowsky S D, Gilliam J N, Tuffanelli D. Epidermal nucleolar IgG deposition in clinically normal skin. Arch Dermatol 1978; 114: 536-8.

8 Reimer G, Huschka U, Keller J, Kammerer R, Hornstein O P. Immunofluorescence studies in progressive systemic sclerosis (scleroderma) and mixed connective tissue disease. sclerosis (scleroderma) and mixed

9 Velthuis P J, Nieboer C, Kater L, Hene R J. A prospective immunofluorescence study of immune deposits in the skin immunofluorescence study of immune deposits in the skin
of primary Sjögren's syndrome. Acta Derm Venereol (Stockh) (in press).

10 Wells J V, Webb J, van Deventer M, et al. In vivo antinuclear antibodies in epithelial biopsies in SLE and other connective tissue diseases. Clin Exp Immunol 1979; 38 424-35.

11 LeFeber W P, Norris D A, Ryan S R, et al. Ultraviolet light induces binding of antibodies to selected antinuclear antigens on cultured human keratinocytes. 7 Clin Invest 1984; 74: 1545-51.

12 Wildschut E G, Velthuis $P$ J, Baart de la Faille $H$, van Weelden $\mathrm{H}$, van Vloten W A. The effects of UV-B and UV$C$ irradiation on the expression of non-histone nuclear antigens on keratinocytes in the pathogenesis of lupus antigens on keratinocytes in the pathogenesis

13 Tan E M, Cohen A S, Fries J F, et al. The 1982 revised criteria for the classification of systemic lupus erythematosus. criteria for the classification of systemic
Arthritis Rheum 1982; 25: 1271-7.

14 Ropes M W, Bennett G A, Cobb S, Jacox R, Jessar R A 1958 Revised diagnostic criteria for rheumatoid arthritis. Bull Rheum Dis 1958; 9: 175-6.

15 McCarty D J, ed. Arthritis and allied conditions. 10th ed. Philadelphia: Lea and Febiger, 1985: chapters 64-7.

16 Claudy A L, Salandre J, Claudy D. Epidermal nuclear IgG deposition in normal skin: characterization by antiribonucleoprotein IgG-Fab fragments. Acta Derm Venereol (Stockh) 1981; 61: 115-8. 